\title{
The local economic impacts of high-speed railways: theories and facts
}

\author{
Corinne Blanquart $^{1} \cdot$ Martin Koning $^{1}$ (C)
}

Received: 8 July 2016/Accepted: 10 March 2017 / Published online: 17 March 2017

(C) The Author(s) 2017. This article is published with open access at SpringerLink.com

\begin{abstract}
Introduction Elected officials and practitioners generally believe that - along with gains in time, environment, and roadway safety - the local economic impacts brought by high-speed railways (HSR) could be a major ingredient in socioeconomic appraisals. However, academic studies have shown mixed results.

Methods This article reviews the various channels through which HSR may impact the local economies. We break down the economic effects by stages of the projects' lifetime and we question the existence of these impacts with an eye towards empirical evidence from the abundant academic and "grey" literature.

Results Outside the "construction effects", that constitute a broad consensus, studies find both the existence and the absence of impacts of HSR, whether these are shortterm effects on local productivity and the geography of consumption (through tourism or extended stays) or long-term effects on the relocation of businesses and households and ultimately local growth patterns. Results show great variability as economic effects are conditional upon a set of other factors such as city size, industry structures, amenities, and distance from the urban core.
\end{abstract}

Martin Koning

martin.koning@ifsttar.fr

Corinne Blanquart

corinne.blanquart@ifsttar.fr

1 IFSTTAR (AME - SPLOTT), East Paris University, 14-20, Bvd Newton, 77447 Marne-la-Vallée Cédex 2, France
Conclusions The main difficulty is being able to identify empirically to what extent new infrastructures have affected variations observed in the field, and not the opposite. We believe that making progress on these questions requires clarifying which model of local development is to be used and what kind of development is the goal of public policy.

Keywords High-speed railways · Socioeconomic appraisals · Base economic theory - Wider economic impacts .

Agglomeration economies $\cdot$ New economic geography

\section{Introduction}

Since the first Shinkansen ("bullet train") was introduced in Japan in 1964, high-speed trains such as the TGV have been an undeniable technological, commercial, and popular success. As seen in Table 1, many countries have invested in what has become a vast network of high-speed rail (HSR) lines, on which trains can run, in best cases, at speeds up to $350 \mathrm{~km} / \mathrm{h}$. In 2016, there was about $35,000 \mathrm{~km}$ of HSR line running worldwide, to which approximately $23,000 \mathrm{~km}$ is projected to be added. ${ }^{1}$

\footnotetext{
${ }^{1}$ The numbers related to HSR under construction or planned have been underestimated because we are only looking at countries with currently existing HSR lines. Table 1 also clearly shows the predominant position of China, which has very quickly built a vast HSR network and plans to extend it in the near future. For more on HSR in China, see Ollivier et al. [88] and Wu [120].
} 
Table 1 International HSR lines, 2016

\begin{tabular}{lllll}
\hline Country & In service $(\mathrm{km})$ & Under construction $(\mathrm{km})$ & Planned $(\mathrm{km})$ & Current rank \\
\hline Austria & 48 & 218 & - & 16 \\
Belgium & 209 & - & - & 12 \\
France & 2036 & 740 & 1786 & 4 \\
Germany & 1475 & 368 & 324 & 5 \\
Italy & 923 & 125 & 221 & 6 \\
Netherlands & 120 & - & - & 13 \\
Poland & 224 & - & 1127 & 3 \\
Spain & 2871 & 1262 & 1327 & 15 \\
Switzerland & 87 & 72 & - & 14 \\
UK & 113 & - & 543 & 1 \\
China & 21,688 & 10,201 & 677 & 10 \\
Taiwan & 345 & 9 & - & 2 \\
Japan & 2892 & 551 & 179 & 8 \\
South Korea & 598 & 61 & 49 & 7 \\
Turkey & 688 & 469 & 1134 & 9 \\
US & 362 & 483 & 1023 & - \\
Total & 34,679 & 14,559 & 8390 &
\end{tabular}

UIC data, accessible online

These statistics include only countries that already have HSR lines in service
These statistics do not show, however, how differently each HSR network functions $[5,97]$. For example, in Japan, the bullet trains run on dedicated tracks, while in France, the interoperability system requires that the TGV be able to run on conventional tracks, and in Spain, some standard trains can use HSR lines. ${ }^{2}$ The motivations behind the investment in these rail systems can also differ ${ }^{3}$ : the initial motivation was to reduce fossil fuel dependency and drive an export-oriented industrial policy; this was followed by a need to alleviate congestion in transport hubs and finally environmental concerns related to fighting climate change. ${ }^{4}$

Despite these differences, a striking similarity is the enthusiasm of local elected officials, who are eager to join the HSR "club", believing that being connected to HSR brings about economic growth. However, academic studies have shown mixed results in terms of the benefits HSR can bring to a region. While certain economic effects of having a HSR connection have been clearly identified and are subject to little criticism, other supposed benefits have been contested in terms of their size, their duration, and whether they occur automatically $[23,56,87,113$,

\footnotetext{
${ }^{2}$ These differences have created some challenges in creating international HSR lines, as is the case in Europe

${ }^{3}$ For simplicity, we use the terms "HSR" and "high-speed trains" interchangeably in this article.

${ }^{4}$ Besides these motivations, the placement of HSR lines can also be set through political deals. See Albalate et al. [4] and Castells and Sole-Olle [26] on how this worked in Spain. Even if less documented, the lobbying activities of the construction industry may be at stake equally.

${ }^{5}$ Besides these references, see also the special issue $\left(n^{\circ} 22\right)$ of Journal of Transport Geography, published in 2012.
}

115]. ${ }^{5}$ This ambivalence is obviously an issue. On the one hand, researchers and practitioners have found that along with gains in time, environment, and roadway safety, the economic impact of HSR lines could be an important factor in cost-benefit analyses recommending that projects be financed [97, 112]. On the other hand, it has been shown that investment in HSR has diminishing financial and social returns [3, 18], suggesting that these rail networks have an optimal size that should not be exceeded. When these two considerations are combined, it becomes clear that identifying and measuring the local economic impact of HSR service is essential from an operational, political, and academic standpoint.

The objective of this article is to take stock of the state of the literature on the local economic impacts of HSR service. We will break down the effects by stages of HSR, given the growing doubts about the existence of these impacts. This review will question the existence of the economic impact with an eye towards empirical evidence from the abundant academic and "grey" literature on the subject. Public policy evaluations, including those on investment in HSR, are especially focused on demonstrating economic effects and are thus based on information that is gathered and interpreted specifically for making policy decisions. This approach tends to put data collection and analysis ahead of research design or creating a theoretical construct of the subject being studied and thus often neglects the theoretical dimension. However, theoretical constructs can counteract 
determinism through a thorough description of the mechanisms through which effects are produced. With no claim to be exhaustive, ${ }^{6}$ this article presents the principal theoretical mechanisms through which infrastructure might affect regional economic dynamics and identifies certain challenges inherent in studying the local economic impact of HSR service. The major interest of this paper is to introduce a new way of considering the so-called "wider economic effects" of HSR services $[47,61,113,115]$. These effects are those not captured in standard cost-benefit analysis, including effects relating to agglomeration, market power, as well as firms' and households' behavioural adaptations. Many researches have focused on the productivity gains due to changes in economic activities' spatial patterns. The article wants to highlight the interest to also analyze changes in local demand and develops the most recent theoretical background to do so. In particular, we show that new HSR services are likely to affect the composition of the local income which, in turn, may have cumulative multiplier effects for the local economy.

This analysis is structured according to the stages of a HSR project, beginning with the launch of construction work. As explained in section 2, most agree that construction sites are the source of the primary local economic impact of HSR. Once the HSR line is in service, time-space shrinking [105] can create short-term economic effects. ${ }^{7}$ Assuming that the location of households and businesses remains stable, HSR can affect the regional means of production through various mechanisms (described in section 3), the identification and measurement of which has been the subject of debate. Aside from any potential effects on local supply, HSR service can also affect individual consumption patterns for goods and services. While the supply-demand dichotomy is simplistic and can overshadow other interdependencies at work, it is possible that HSR service can also have a short-term demand-side effect on local economies (as seen in section 4). Depending on the existence and magnitude of these two types of effects, HSR can change the relative attractiveness of a region in the medium to long term. Transport infrastructure can thus shape local economic development by driving businesses and households to relocate, with various and uncertain effects on the direction of growth (section 5). The conclusion summarizes the various findings of this article.

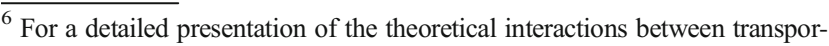
tation infrastructure and local development, see Venables [114], Proost and Thisse [92], and Lafourcade and Thisse [73]. For an exhaustive review of the literature on HSR, see Vickerman and Ulied [115], Givoni [56], Albalate and Bel [5] and Ollivier et al. [88].

${ }^{7}$ In this research, we consider the "short-term" to range from 0 to 5 years after the HSR opening, the "medium-term", from 5 to 10 years and the "long-term" for later periods. Whilst being discretionary, this definition assumes that firms and households' locations are fixed in the short-term.
}

\section{Construction effects}

Economists are unanimous in recognizing that public investments are an essential component of effective demand [1], i.e. the anticipated demand entrepreneurs base their production decisions on. In an underemployment equilibrium, Keynesian theory prescribes an increase in public spending to keep economic activity at an acceptable level. These considerations have been central to countercyclical economic policy, from the New Deal to the Obama administration's 2008 economic recovery plan and the Juncker plan in Europe (2013). Given its importance in total state spending [103] and proven macroeconomic effects [21], transportation infrastructure, particularly HSR, has a preferred place in stimulus policies. ${ }^{8}$ Spending dedicated to new transportation services ${ }^{9}$ has thus been the object of several studies aiming to quantify job and wealth creation linked to infrastructure construction projects $[34,76,86,121]$. The direct impact of HSR is generally an integral part of official socioeconomic impact studies, although each country has its own conditions for advancing with such projects.

Since transportation projects occur within a circumscribed area, studies estimating construction effects are often based on two different theoretical models: the input-output model and economic base analysis ${ }^{10}[65,72,82,95,104,106]$. Based on Keynesian theory, economic base analysis stipulates that the development of cities or regions is essentially driven by exogenous variables over which they have no influence. Initially focused on export activities (for a "renewed" framework, see section 4), this theory demonstrates that the wealth earned outside the region under study (basic activities) stimulates the rest of the local economy (non-basic activities) with cumulative effects that are proportional to the magnitude of the multiplier. Since the majority of financing for HSR projects comes from national governments through a system of fiscal equalization among regions, investment spending can be seen as coming from a source other than the local economy and thus similar to revenue from basic activities.

To evaluate the magnitude of the construction effects of a new HSR line, the standard procedure is to identify direct spending (e.g., the workforce necessary for grading or contracts with the main subcontractors), indirect spending (products and services ordered from local suppliers by the workforce and subcontractors), and induced spending. As such, every euro spent on a HSR project will create further

\footnotetext{
${ }^{8}$ While Obama's plan explicitly contained an ambitious investment program in HSR, the Juncker plan favours national policies in this sector, which limits the financing of international projects aiming to connect various EU member states by HSR.

${ }^{9}$ De Rus et al. [97] estimate that one kilometre of HSR requires an average investment of 17.5 million Euros, not counting rolling stock.

${ }^{10}$ If they are correctly specified mathematically, the input-output and economic base models are equivalent [95].
} 
consumer spending in sectors more or less related to construction. The impact of these various expenditures is a function of the propensity to consume wealth locally. The effects of the initial investment can vary by local economy depending on whether the construction workers live near the worksite or commute and thus spend only a small fraction of their wages in the region. The effect will also vary depending on whether the construction materials come from local subcontractors or are imported from other areas. To the extent that the Keynesian multiplier, in the form of production, value added, or job creation, is the inverse function of the propensity to consume locally, the magnitude of these "drains" moderates that of the construction effect. The empirical implementation of these models requires knowledge of the volume and composition of the funds invested in constructing HSR lines as well as the inter-industry flows, ideally on a fine-grained spatial scale to understand how different areas of the local economy react to such construction projects.

Ex-ante estimates of construction effects often show substantial gains, and thus provide an argument in favour of building infrastructure. In the case of the High-Speed 2 (HS2) train that is projected to connect London to North England (Leeds, Manchester, and the Midlands) by 2026, more than 22,000 jobs could be created directly and indirectly in the five years following ground-breaking [50]. Another example is the planned "Basque $Y$ " high-speed line that aims to create a HSR connection from the Spanish Basque country through the existing Atlantic high-speed corridor to southern Europe (Paris-Bordeaux-Vitoria-Madrid) by 2020. This large construction project is expected to create 100,000 jobs, $40 \%$ of which will come from direct effects, $30 \%$ from indirect effects, and 30\% from induced effects [52]. Finally, a recent study [24] estimates the number of jobs from direct, indirect, and induced sources that could be created in three California counties that are projected to have HSR service by 2020 . Depending on the alternatives considered, the project could create 10,000 to 16,000 jobs in the five years of construction, $30 \%$ of which should come from direct effects.

Since, however, the results of ex-ante studies are uncertain by definition, it is useful to look at the ex-post study undertaken by Fouqueray [53], who looks at the construction effects linked to the first construction phase of the SEA HSR line that will link Tours and Bordeaux by 2017. By crossing an input-output model with fieldwork among the businesses and employees involved in the construction, Fouqueray [53] concludes that the project created almost 14,000 jobs, 1.6 billion Euros in production, and 755 million Euros in value added in the 3 regions involved in the construction; the induced effects made up $18-25 \%$ of these gains. From these results, Fouqueray [53] finds multipliers that are consistent with previous studies [34, 76, 121], especially those used in France by RFF [94]: 1.96 for production, 0.91 for value added, and 2.44 for job creation. In other words, each job related to the construction project meant
2.4 jobs for the local economy. Since this information applies to $43 \%$ of the project, it would seem that the direct economic impact of HSR construction is significant.

This brief review of the construction effects of HSR projects brings up several points. First of all, the direct economic effects are more significant if the area under construction is large, since the propensity to consume locally will be stronger. The economic benefits are also temporary by definition, although some skills that businesses or employees develop during projects can be used in subsequent jobs (see Fouqueray and Manceau Antoniazzi [54]). ${ }^{11}$ It is also important to note that the methods used to estimate the construction effect can also be used to understand the economic impact of the operation and maintenance of HSR lines. On the downside, these large construction projects run by major public-works firms can destabilize local building and public works activities and make permanent structural changes in the affected sectors. However, the anticipated opening of HSR connections can act as a signal for public or private actors to make other investments such as real estate projects near the station or improving public transportation networks and community facilities. In this way, the effects of infrastructure projects are often enhanced by the creation of other jobs and wealth through projects related to the HSR line. Overall, it is essential that all these potential benefits be properly considered since the investments are funded in part by local governments, who need to make a case to voters that their financial resources are being used wisely. By reducing unemployment and providing a cash infusion to the local economy, the construction effect can make HSR projects more politically acceptable. In addition, the officials who are generally prone to communicate about these direct benefits of their decisions may expect positive rewards during the next elections (local and/or national).

\section{Short-term supply-side effects}

Even though HSR passengers have to pay more for their tickets, the establishment of this type of infrastructure leads to significant time savings, ${ }^{12}$ allowing high-speed trains to compete with air travel for medium or long distances [25]. This reduction in generalized travel $\operatorname{costs}^{13}$ has an effect on

\footnotetext{
${ }^{11}$ With that respect, one critical issue relates to the local "governance" of the organization created for the HSR construction. As studied by Fouqueray and Manceau Antoniazzi [54] in the case of the SEA project, the mutual trust and continuous relationships linking the local actors (unions, jobs agencies, local governments) to the private company in charge of the HSR building played as a necessary condition for recruiting the relevant workers as well as for securing their workability once the construction phase completed.

${ }^{12}$ Some of the time saved is a result of more direct HSR routes.

${ }^{13}$ Some authors challenge this decrease in generalized costs related to HSR by using the concept of "effective social speed" [40]. Effective social speed takes into account not only commute times but also the work hours necessary to pay for the significant expenses paid by travelers as well as the public subsidies often granted to HSR.
} 
companies, especially those that offer business services (e.g., audit, marketing, R\&D), whose employee mobility and thus market area thereby increases. The decrease in generalized costs and the induced increase in business trips are generally taken into consideration as changes in traveler surplus as part of the cost-benefit analysis for the socioeconomic impact studies of a potential HSR line. The wider economic impacts that decision-makers often envision, which are a subject of debate in the academic community, are another matter. Aside from its direct impact on transportation, HSR can improve local business activity by changing the operation of sectors affected by market failures. In order to determine the nature of these effects, it is useful to look at the UK's official recommendations on transport analysis, which initiated close cooperation between researchers and practitioners on this topic $[46,58$, 102, 113, 114].

Within a partial equilibrium framework that notably excludes interactions between transportation and choice of location (see section 5), the UK's Transport Analysis Guidance (TAG) [46] recommends first appraising welfare gains linked to lower production costs in sectors with imperfect competition. By reducing the resources firms devote to offering their services, HSR generates consumer benefits that are more than proportional to the increase in time savings. A new HSR connection in fact means increased competition, which means increased local production along with lower retail prices. ${ }^{14}$ New transportation options can also change the dynamics of labour market arbitrage in terms of whether an individual will enter the market. By increasing the supply of employment, HSR projects can have locally beneficial effects that can be estimated using changes in public finances (increases in payroll tax payments and decreases in welfare payments). Above all, the main effect of HSR projects on the quality of the local means of production stems from the relationship between accessibility and urban productivity. ${ }^{15}$ By reducing the transportation costs between two regions, HSR will change effective economic density, ${ }^{16}$ i.e. the density of activities in a

\footnotetext{
$\overline{14}$ The associated welfare gains are estimated by assigning a coefficient of $10 \%$ to time savings for business travel; this coefficient includes mark-ups from monopolistic firms and the elasticity of demand [47].

${ }^{15}$ TAG identifies two other indirect economic impacts of transport infrastructure $[46,88]$. One involves individual employment changes to more or less productive jobs due to improved labour market matching. Moreover, various quantitative and qualitative changes to the labour market can change employees' and businesses' tax payments and thus the state of public finance. Because these two effects occur in the long term, they do not fit in the partial equilibrium model and are assumed to be found in other methodologies (see section 5). TAG thus specifies that it is not necessary to quantify these wider economic effects.

${ }^{16}$ The concept of effective density is similar to that of urban accessibility (which only considers spatial area), which in itself is not very different from the concept of connectivity (which includes the concept of access to transportation). See Vickerman and Ulied [115] and Crozet [39]. Some studies, using theories based on international trade or New Economic Geography, use the concept of market potential (see, for example, Ahlfeldt and Feddersen [2]), which is quite comparable.
}

geographic area and the neighbouring areas that can be reached within an acceptable commute time (60-90 $\mathrm{min})$. On the other hand, a great deal of literature in the field of New Urban Economics has shown that there are productive advantages linked to the spatial concentration of activities, otherwise known as economies of agglomeration [37, 49, 84]. Effective density gains are multiplied by an empirical measure of elasticity of productivity with respect to spatial concentration, differentiated, if possible, by economic sector [60], to determine the wider economic benefits generated by a new HSR connection. ${ }^{17}$

This method has allowed for ex-ante estimates of the anticipated economic impacts of the proposed HSR connection to North England, HS2. The results are quite significant since the gains from increased urban productivity could reach 700 million to 1.3 billion pounds every year [61]. These benefits correspond to about $3-4 \%$ of the discounted net effects of the project and could help justify the initial investment of 50 billion pounds. Hensher et al. [64] carried out a similar exercise to estimate the wider economic impact of a proposed HSR connection between Sydney and Melbourne. Their calculations provided results of a lesser magnitude since the productivity gains from increased effective density for business travel only added up to \$A10 million a year. Finally, SETEC [100] transformed gains in urban accessibility created by the proposed HSR connection Paris-Orleans-Clermont-FerrandLyon (POCL) into local economic performance gains. Every year the new infrastructure could create economic gains of almost 87 million Euros, i.e., $20-25 \%$ of the anticipated time savings from the proposed rail connection. Even if they are not sufficient to justify the initial investment of 12.9 billion euros, these benefits are likely to improve the socioeconomic balance of the POCL project.

Ex-post studies of the interactions of increased proximity through HSR and local productivity are more difficult to find [88]. A notable exception is the work of Ahlfeldt and Feddersen [2] on the HSR line that has connected Cologne and Frankfurt since 2001. They observe that six years after the HSR line was installed, the GDP of the regions between the two stations increased $8.5 \%$ faster than if the project had not been implemented. From these calculations, they estimate the elasticity of productivity with respect to density to be almost $3.8 \%$, which is consistent with past empirical results [84].

Even though this approach is practical and provides statistical arguments to complement traditional cost benefit analysis, several studies have criticized it [39, 47, 68]. To the extent that these models attempt to appraise the local economic impact of transportation projects, the lack of sufficient data is one

\footnotetext{
${ }^{17}$ A similar approach was used in France until recently, except that it transformed increased access (not effective density) into GDP gains. In fact, in France the statistical correlation between accessibility and local productivity is close to unity [39].
} 
limitation, since data on business and employee productivity is not always available on a fine-grained spatial scale. Above all, the econometric studies from which flow certain key parameters, such as impedance of demand for transport relative to generalized cost or the elasticity of productivity relative to density, can have endogeneity problems due to causal inference, especially reverse causality and omitted variables. ${ }^{18}$ In fact, while HSR most likely improves effective density or accessibility in a region, it could be risky to transform the increased economic opportunity into productivity gains [39]. In their study of mid-sized German cities connected to a HSR line for exogenous reasons, Ahlfeldt and Feddersen [2] are quite convincing in this regard. While they establish a causal relation between effective density and local productivity, the authors also show that the intensity of economies of agglomeration declines rapidly with travel time. Moreover, the positive effect of density on local productivity is no longer significant when they add industry mix and employee skills to their regressions, demonstrating the importance of spatial sorting $[19,36] .{ }^{19}$

Aside from these empirical challenges, there are also conceptual and theoretical problems in determining the wider economic effects of HSR on the local means of production. As Kanemoto [68] points out, the British TAG approach tends to ignore the negative impacts on cities outside the HSR network, which creates at least two problems. For one, a Spanish case study showed that instituting HSR lines can mean a relative loss of accessibility for certain areas, mostly due to inferior service on the standard railways [80]. More importantly, the TAG approach has trouble making a clear distinction between the movement and the net creation of wealth, only the latter of which should be counted as a wider economic benefit of an infrastructure project [113]. It is thus easy to overestimate the benefits of HSR for certain areas while ignoring losses for other areas. Finally, it is important to recall that ex-ante estimates of the wider economic impacts of HSR are hypothetical by definition. The use of these estimates by

\footnotetext{
18 In the case of reverse causality bias, local productivity would dictate the routes of new transportation infrastructure and not vice versa. Omitted variable bias would arise if a variable that the modeller does not observe simultaneously influences the HSR's supplies and local productivity. If these two phenomena are present, the estimation of the effect of effective density on local productivity will be biased and thus not conducive to correct projections. One other critical issue relates to the costs arisen from an excessive spatial agglomeration. Actually, the estimates of agglomeration economies should ideally account for the nuisances linked to transport congestion, environmental pollution, criminality... As explained by Combes and Lafourcade [37], most estimates found in the literature rather describe the "net" effects because they do not distinguish the positive and the negative outcomes of density. For empirical works on diseconomies of agglomeration, see Graham [59] and Combes et al. [38].

${ }^{19}$ With spatial sorting, variations in productivity are not explained by variations in effective density (affected by HSR) but more by the fact that the most competent workers or the sectors with high value added tend to move into the densest spaces. Bouba-Olga and Grossetti [19] thus show that the apparent surproductivity of the Paris region is clearly reduced once the estimates control for sectoral specializations and jobs' composition.
}

businesses or workers could lead to the implementation of strategies or routines that are difficult to model and are not systematic, since they do not emerge until the medium to long term, which does not fit within a framework of partial equilibrium analysis.

These various arguments ${ }^{20}$ thus help in understanding the doubts surrounding empirical measures of productivity gains related to the introduction of HSR. It is also worth noting that in the case of the HS2 project, Graham and Melo's [61] estimates are much lower than those produced by a consulting firm for the British government [71]; this gap was highly publicized and debated in the British media. ${ }^{21}$ Certainly it is likely that new transportation infrastructure will have a shortterm influence on the local productive supply, mostly through economies of agglomeration or an increase in competition. However, due to problems in identifying or measuring these indirect effects, their use in official socioeconomic calculations has been uneven. While this practice is now required in England, the German approach to calculating indirect effects is much more qualitative ${ }^{22}$ [88], and perhaps more prudent. Other countries, like France, do not try to appraise these economic effects of HSR and are waiting until there is more unanimity in this field.

\section{Short-term effects on local demand}

As well as influencing production, HSR can also change consumption patterns and thus generate wider economic effects through local demand. Davezies [41] shows that export activities, which are subject to economies of agglomeration, have only a secondary role in the revenue of French regions, while the majority of local wealth comes from public transfers (pensions and civil servant salaries) or from expenditures of residents and/or tourists. Through this framework, HSR is a factor in separating the areas where revenues are created from those where they are spent. HSR, in fact, has the same effect as airports on attracting wealth [107]. In terms of economic base analysis (see section 2), tourism and commuting have a similar role to basic activities in that they induce interregional transfers with a short-term multiplier effect.

Before HSR projects are completed, there are strong expectations of positive effects on tourism [10]. The argument is that improved accessibility will increase demand for

\footnotetext{
${ }^{20}$ Kanemoto [68] formalizes other limits of the wider economic impacts promoted by TAG, notably the links between the cost of public services and the variety of goods offered.

${ }^{21}$ For example: http://www.telegraph.co.uk/news/uknews/road-and-railtransport/10427468/HS2-benefits-essentially-made-up-economists-tell-MPs. html

${ }^{22}$ As explained in Ollivier et al. [88], the German guidelines combine a quantitative analysis of the employment effects (due to the increased division of labor among regions) with a qualitative scoring of projects (depending on their impacts on territories characterized by structural backwardness).
} 
transportation and thus spur business and leisure travel $[9,44$, $67,81,91,98]$, bringing with it higher local revenues and tax receipts. HSR could also stabilize occupancy rates at hotels and reduce seasonal effects in the tourism industry. Such exante beliefs were in force in Kent, UK, where at the end of the 1980s tourism was seen as the main economic opportunity of the launch of the Channel Tunnel [55]. Rietveld et al. [96] also found that Amsterdam's tourism industry would greatly benefit from future Thalys HSR service. In Spain, local businesses anticipated a HSR connection in Lleida to be such a great opportunity for promoting tourism in the Pyrenees that the station was called Lleida-Pirineus [51] in [45]. Chen and Haynes [31] find that in China, provinces with HSR would have $20 \%$ more tourist traffic, which would generate $25 \%$ more revenues than in provinces without HSR service. HSR is thus thought to enhance a city's competitive edge in tourism and thus create wider economic benefits for the region served.

The results of ex-post analyses, however, are much more mixed. A study carried out by DB International GmbH [42] of pairs of cities with and without HSR service in France, Germany, and Spain shows that it is impossible to generalize trends in occupancy rates in the regions connected to HSR [39]. A SEEDA [99] study of 13 cities in Germany, the Netherlands, the UK, and France shows that "few of the cities seem to have experienced a boost in tourism through HSR connections" [45]. On the other hand, an increase in leisure travel was found in Taiwan [32], China [116] and Japan, in certain cities with HSR service, while tourism rates declined in cities without HSR service. This heterogeneity in results can be better understood through the model of travel destination choice created by Woodside and Lysonski [119], which highlights the effects of several interdependent variables, including individual traveler characteristics, territorial marketing (destination awareness), idiosyncratic traveler destination preferences, and situational variables.

Above all, city size seems to play a critical role in the positive dynamics brought about by HSR: tourism growth linked to HSR service is found in major cities, or cities that are quickly and frequently accessible to major cities with famous, well-publicized, and diverse tourist attractions [43]. In Spain and France, Urena et al. [111] emphasize that intermediate cities with HSR service (Lille, Saragosse, and Cordoue) have seen growth in leisure and business travel. Similarly, Todorovich et al. [107] find that in Lleida, tourism grew by $15 \%$ annually and business conventions increased by $20 \%$, unlike in Tarragone, where the rail station is distant from the most attractive coastal areas [45]. In France, Bazin et al. [11] find that in some small and mid-sized cities with tourist amenities, despite HSR service through the North, Atlantic, or Eastern European lines, tourism increased only slightly. Positive effects of HSR service can be found for intermediate cities if the regions already offer a "market basket" allowing for a diversity of tourist activities [11], along with sufficient high-quality hotel supply $[9,10,108]$.

While the increase in tourism in certain cities cannot be generalized, it is also important to recognize the potential negative effects of HSR. Certain expectations have been disappointed, notably due to a decrease in length of stays. In France, a review of the South-eastern HSR line found that the length of stays in the main urban centers served by this line decreased as the number of day trips increased from $42 \%$ to 55\% [88]. In Lyon, the arrival of HSR certainly contributed to the arrival of major national trade fairs, but it also resulted in a reduction in the length of stays, from 2.3 to 1.7 days in 1993 [77]. Okabe (cited by [96]) also shows a reduction in stays of one night or more in Japanese cities with HSR connections [45]. In China, the HSR connection in Hangzhou could have a negative impact on the hotel business since it is now possible to visit the city as a day trip from Shanghai [29]. Even though the number of visitors might increase when a HSR connection is established, this could be offset by the decrease in the length of stays, leading to a decrease in total tourist spending [75], which shows the contradictory effects of HSR connections on local demand [3]. It should be noted that our review is focused on cities that attract tourists, overlooking the negative consequences to regions experiencing a drain of their population and revenue. ${ }^{23}$

While the literature includes numerous case studies on the interactions between HSR and the development of tourism, it is difficult to find studies that have quantified the associated economic effects. Given the statistical problems discussed above and the simplifying aspect of modeling approaches, the results of these studies should be considered with caution, which explains why these studies are not used in government socioeconomic impact studies. Aside from Chen and Haynes's study [31] on China mentioned above, SETEC [100] translates into monetary units the accessibility gains to natural amenities linked to the POCL HSR project. The wider economic effects connected to ecotourism added up to 5-9 million Euros per year, or a 10\% gain in economic efficiency created by the growth in productive opportunities. Moreover, Hensher et al. [64] studied projected non-business travel, some of which was related to tourism, for the future HSR connection between Sydney and Melbourne. While the productivity gains due to business travel are modest in comparison to the UK results (see section 3), increases in effective density due to individual mobility could induce a considerable

\footnotetext{
${ }^{23}$ As Davezies [41] explains, the Ile-de-France area is certainly the most productive region in France, even if most of the differential with other French territories is due to sectoral specializations and the presence of highskilled workers (see footnote 19). Since its residents are highly mobile in terms of non-business travel, which is facilitated by excellent HSR connections, the Ile-de France is now suffering from a local consumption deficit. Despite the substantial flow of foreign tourists to the French capital, this revenue drain has an adverse effect on regional unemployment.
} 
increase in economic welfare: approximately \$AUS 1 billion. Finally, Koning et al. [70] estimate the propensity to consume locally on a sample of 231 French cities. They conclude that the proportion of revenue spent outside the area depends on the difference in amenities between the cities but increases as travel time decreases. This proportion is higher in cities that specialize in hospitality as opposed to areas that are essentially oriented toward export activities. If the latter have HSR connections, they will experience a major wealth drain with negative multiplier effects.

To complete this picture of the possible short-term effects of HSR on the intensity of local demand, we note that HSR connections could also lead to the development of new ways of life by turning tourists into short-term or part-time residents [79]. As seen in section 3, HSR has the potential to expand the size of labour markets due to daily or possibly weekly commutes for longer distances [114]. This phenomenon would have a similar effect on local demand to that of tourism because both distinguish production from consumption areas. An increase in daily HSR commuters has been observed in Spain, France, and Sweden. There has thus been a substantial increase in the number of commuter trains between, for example, Puertollano and Madrid, with the number of direct trains increasing from 18 in 1992 to 47 in 2005 [89, 110]. Regular trips (once to several times a week) from Lyon or Le Mans to Paris have also increased significantly. Rietveld et al. [96] even refer to Lille as a commuter town for people working in Paris, Brussels, and London. Other studies, however, show the absence of systematic effects; thus generalizing the results remains difficult. For example, in the case of the Atlantic TGV line in France, it is not possible to claim that the total number of daily or weekly commuters has increased; in fact, it seems most likely that weekly commutes have been replaced by daily commutes [69]. These new mobilities have influence on the economy. Income from tourism might then be falling in many destinations despite the increase in visitor arrivals, due to a reduction in the length of stay. Secondly, it is possible to observe knock-on effect due to a more seasonal demand and greater pressure on the tourist area and on the tourist accommodation [6]. Regarding daily commuting, it is well known that workers tend to spend their money near their place of residence. A research from Shields and Deller [101] illustrates that an additional in-commuter increases local retail sales by about $\$ 7600$ whereas when a household migrates into the region, total sales increase by about $\$ 20,200$ [101].

Despite these mixed results, two hallmarks seem to have emerged. One common finding is that commuting is generally more favourable to large cities, since HSR reinforces the economic and demographic urbanization of the region. This infrastructure primarily allows urban populations to spread into the hinterlands - the countryside and small adjacent cities. This effect on commutes depends on the distance: it seems that for trips of $2 \mathrm{~h}$ or more, the effects are independent of changes in rail service. On the other hand, introduction of HSR has a primary effect on one-hour connections and secondary effects on 90-min commutes [69]. In Spain, Urena [109] shows an impact on commutes for trips between 45 and $90 \mathrm{~min}$, not taking into account travel to and from the station.

In the end, the extreme diversity of these situations highlights the need to contextualize HSR's effects on local economies, in tourism as well as in other sectors [12]. The mobility created by this new infrastructure reveals other determining factors, specifically the size of the affected area and whether a region is specialized in hospitality, whether temporary or permanent. If they in fact exist, the economic effects of HSR stemming from local demand are far from automatic. It is therefore necessary to analyze them in terms of HSR's entry into specific regions.

\section{Medium- and long-term effects}

It has been unanimously recognized that a decrease in transportation costs modifies the spatial distribution of economic activity over the medium to long term [73, 92]. Various studies of the United States in its westward expansion period [7], the Kingdom of Prussia [66], and colonial India [48] have shown that in the nineteenth century, railroads led to the concentration of employment and thus population in certain areas, with long-term effects on agglomeration. These economic impacts of railroad service can be explained by a decrease in transportation costs for merchandise. HSR, on the other hand, affects the transportation costs for individuals. Given the steep decline in freight transportation costs over the long term, the resources involved in individual mobility are now one of the factors necessary to understand regional and urban dynamics [57].

The theoretical contributions of the New Geographic Economics $[8,35,73]$ and the empirical tests used for spatial models of computable general equilibria [20] allow these phenomena to be studied by describing the interactions of various markets. These approaches have been used in Japan for exante appraisals of the long-term effects of HSR as part of government socioeconomic impact studies [88]. Among the benefits associated with a given area, such as a densely populated city, are the specific resources necessary for economic activity (specialized labour or varied intermediate goods), intra- or intersectoral externalities, and indivisible equipment. Among the costs associated with this given location are competition in the market for goods, services, labour, and real estate; transportation congestion; and environmental pollution. In the end, firms realize a trade-off between these agglomeration and dispersion forces and they choose the location that maximizes their market potential [35]. Economies of agglomeration and the associated competitive gains in export- 
oriented firms lead to the home market effect [83], in which major urban centers have the tendency to host a majority of export activities, to the detriment of outlying areas.

Since transportation costs help shape a company's market potential, new infrastructure can influence its choice of location and encourage it to move to more productive spaces. Hall [63] and Preston and Wall [90] thus posit that the spatial impact of new HSR lines is certainly complex, but they seem to favour the major metropolitan areas, especially downtown areas, to the detriment of the periphery. ${ }^{24}$ From a theoretical point of view, however, the new transportation supply does not have a linear effect on spatial distribution and could even work against the interest of the center, depending on the mobility of the factors of production $[35,73,93]$ : While a change in transportation costs from high to moderate level leads to a polarization of economic activities in major urban areas, the change from moderate to low costs could allow businesses to move back to the periphery. In fact, companies could thereby avoid excessive competition in the labour and real estate market while being easily accessible to consumers. Households could use a similar logic and choose to live in cities they find more pleasant and where real estate is more affordable ${ }^{25}$ while still being able to commute to work using HSR [16].

However, when these theoretical predictions are studied empirically, often in qualitative studies of varying types [88], the results are also quite mixed. In Japan, Nakamura and Ueda (1989) (cited in [98]), show that three of six prefectures with HSR service experienced population growth above the national average in the 1980s, while none of the prefectures without HSR service grew above the national average. Using a longer timeframe, Cervero and Bernick [27] observe that in the 30 years since the Shinkansen was inaugurated, the gaps in employment and population between major cities like Tokyo and Osaka and intermediate cities have not decreased. The economic role of cities like Nagoya and Kyoto and their position in the urban hierarchy has in fact relatively weakened. Finally, Cheng et al. [33] show that 10 years after the launch of various HSR lines in northern Europe, job growth in London, Brussels, Amsterdam, and Cologne was superior to national averages or averages in the hinterlands. These examples point toward a polarization of economic activities in major urban centers that has been exacerbated by HSR. Nevertheless, we cannot conclude whether it is the HSR connection that creates

\footnotetext{
${ }^{24}$ As seen above, productivity gains due to increased accessibility often work in the favour of denser areas, which encourages firms to invest there [30] and attract workers due to higher salaries $[36,113]$. It also seems that growth in tourism (and the potential associated spending) is stronger in downtown areas with varied amenities, creating another cumulative asset for that area.

${ }^{25}$ To make a parallel with the indirect benefits of HSR due to increased urban productivity, new infrastructures could also generate negative diseconomies of agglomeration. This would be the case if the improved accessibility of connected cities leads to one excessive rise in land prices. Also, the growth in tourism visits or inverse commuting may exacerbate overcrowding in transport networks or in the public spaces, thus affecting the quality of urban life.
}

growth or whether it is the anticipated growth in these areas that attracts infrastructure investment. In other words, these ex-post studies do not allow a causal relation to be established between HSR and local growth, especially since HSR lines have often coincided with highway system expansions, particularly in France [70, 74].

Other empirical studies suggest that HSR connections do not only work in favour of the biggest cities. Ahlfeldt and Feddersen's [2] study on the HSR connection between Frankfurt and Cologne showed that the shock to access on small cities with exogenous connections to the HSR lines because of their location between the two stations created persistent growth in local per capita revenue, with relocation of jobs and population to those areas. Examples in France and Spain also show that dynamic regions located 60-90 min from a major metropolitan area are the most likely to receive HSR service [88]. However, within these regions, since intermediate areas (with 50,000 to 100,000 residents) could potentially attract neighbouring residents, the net effect on the local population could be modest. In addition, certain regions have not seen an increase in employment due to commuting but have seen increased revenue due to the high salaries their residents earn in major urban centers and then spend in their residential area.

The case of the South-eastern TGV line [17] shows that contrary to the initial fears that Parisian firms would inundate Lyon market, business service companies have in fact developed outside of Paris. ${ }^{26}$ As Charnoz et al. [28] show, the decrease in communication and transportation costs spurred by HSR allowed multi-office companies (generally headquartered in Paris) to create jobs in regional offices (in Lyon, for example), thus enhancing functional specialization and productivity. ${ }^{27}$ For other authors, however, the Southeastern TGV line was not the sole determinant of these relocations but one criterion among others to distinguish between alternatives that would otherwise been similar [88]. In England, the most significant effect of HSR service in South England has been observed in cities close to London, especially urban centers $1 \mathrm{~h}$ away from London that benefited from a growth in both population and employment, especially in knowledge-intensive business services [88]. Puga [93] and Chen and Silva [30] similarly argue that the primary effect of HSR is on the location of businesses services and major company headquarters, which benefits a few large cities. On the other hand, the increase in real estate prices in those cities make them less attractive for industry, leading to a move from an economic geography based on sector-level specialization to one based on specialization by function.

\footnotetext{
${ }^{26}$ This can be seen in a $52 \%$ increase in business travel caused by Paris firms as well as a $144 \%$ increase in business travel originating from firms located in Lyon metropolitan area.

${ }^{27}$ These organizational effects of HSR have also been seen in Japanese multioffice firms after Shinkansen lines were extended [13].
} 
These favourable conclusions for HSR cannot be generalized, however, as they depend on the spatial scale of the analysis, the statistics used, or hindsight. Graham et al. [62] show this in their study of the influence of HSR infrastructure on labour dynamics in Spanish regions. In order to correct for endogeneity problems in their estimates, the authors used the difference in differences technique: This technique, based on medical research methods, examines the treatment effect by randomly assigning a population to either a treatment group or a control group. ${ }^{28}$ At the end of the exercise, Graham et al. [62] did not observe any significant difference in the employment growth rate between regions with and without HSR connections, nor were there differences before and after the arrival of these connections. Crozet [39] also observes an absence of correlation between employment growth and the progressive extension of HSR in France. Finally, recent studies show that the effects of new Shinkansen lines are not as beneficial as they were previously [85] and that in fact, Shinkansen may have simply supported existing growth rather than actually inducing it [98]. In the end, these results reinforce the general accepted conclusion that HSR connections in themselves do not guarantee local economic development [88]. At most these connections can be seen as a necessary but insufficient condition [87], once again highlighting the need to contextualize their effects. The scientific approach of systematic "structuring" infrastructures effects is then often criticized, because it forgets the socio-economic characteristics of the areas, but also the influence of the accompanying strategies. National constraints but also resources of the areas have thus an influence: these resources can be specific, resulting from either geographical, natural conditions or specific historical conditions, or from the stakeholders strategies. It means that territorial dynamics do not exist as such, but are the results of stakeholders accompanying strategies.

Taking the context of the effects into account does not, however, solve the problem of causality, since an effect, even if conditional, is still an effect. Other studies $[14,15]$ find that the influence of transportation cannot be studied without considering the options businesses have selected in their relations with other actors in systems of production. The essential question is how the relation of these actors is structured. The analysis of the mechanisms that contribute to the compatibility of agent behaviour in interactions $[117,118]$ is based on studies of coordination. In this framework, development is seen as the result of a coordination process more than as a state dependent on factor endowments and exogenous factors. This reduces the inherent bias inherent in terms of effects since infrastructure is considered as one factor among others in the coordination of agent activity. It is thus possible to critically examine the role of infrastructure in terms of the support it provides to

\footnotetext{
${ }^{28}$ In this case, Spanish regions without HSR service and some Portuguese regions.
}

actors' movement and coordination in general. The pertinence of public infrastructure projects can hence be seen in the light of coordination mechanisms. Transportation is thus a strategic activity whose terms need to be adapted to the mechanisms of trade and interaction among firms (coordination mechanisms). Complementary qualitative interviews can then be conducted to understand the resources (among which infrastructures) involved in the production process (made of "transformation activities" and "circulation activities") as well as the coordination mechanisms between actors (beyond the classical ones by the prices or the rules or institutions). Through a correspondence factor analysis, this qualitative material could be useful to build a typology of the "transformation activities", to which are associated specific coordination mechanisms and "circulation activities". Interactions between the transformation process and its environment of resources, suppliers, customers and other producers form a system of circulation of goods, information and knowledge. Transportation thus becomes a particular set of techniques of interaction in the space-time grid [22].

Nevertheless, it should be noted that NGE models point to various challenges that regional development policy must overcome $[35,92,93]$. These models explain why the decline in inequality seen in EU member countries was accompanied by an increase in sub-national inequality. European politicians face the cohesion-competitiveness dilemma: While the goal of investments, particularly in HSR, is to improve EU integration and break the isolation of the periphery, these investments can also reinforce the dominance of major urban centers. Brocker et al. [20] use a CGE model to estimate the impact of a transEuropean transportation network, including various HSR projects. While the periphery experiences increased per capita revenue, it will probably not see a reduction in the gap that separates the periphery from the dominant regions. Puga [93] confirms that if there is little interregional travel and salaries are relatively homogeneous, infrastructure will have either very little impact on poor areas or will aggravate the wealth gap. ${ }^{29}$ These ambiguous effects of EU regional policy seem to be confirmed by studies that combine NGE and endogenous growth models $[8,78]$. These theoretical analyses conclude that an inequitable spatial distribution of economic activities, exacerbated by a reduction in mobility constraints, could coincide with economic benefits for the country as a whole with positive effects for even peripheral regions given localized technological externalities or knowledge transfer. From this perspective, HSR is not a zero-sum game, but rather a situation in which all regions can see an improvement. As mentioned in section 3, making a clear and quantified distinction

\footnotetext{
${ }^{29}$ A note from the OECD notes that among the 8 countries that experienced a decrease in regional inequalities between 1995 and 2005, 5 of them, including Spain, had HSR service. Nonetheless, the introduction of HSR connections was only a part of a set of government actions linked to this decrease [88].
} 
between displacement effects and net gains driven by HSR is a theoretical and empirical challenge of a high order that will require substantial future research.

\section{Conclusion}

The link between transportation and development is one of the most solidly anchored myths in economic development on any scale. The magnitude of investments in infrastructures and their irreversibility make it crucial to clarify the question of whether this spending in fact contributes to the development of the regions they serve.

This review shows the doubts remaining in evaluating the effects of HSR. The only point most studies agree on is that HSR connections generate induced traffic due to the decreased generalized cost of transportation created by increased access. This effect thus has a preferred position in cost-benefit analyses through changes in users' surplus. The other potential effects of HSR have had a more mixed reception: of course, a ripple effect can be observed among suppliers linked to the construction project. The spread of these effects proceeds through demand and, in varying proportions, salary distribution: the higher the share of earnings linked to HSR buildings consumed on the considered territory, the higher the Keynesian multiplier and positive impacts for local employment. However, these effects are limited in space and time and allow for on the one hand technological and organizational learning by the companies involved and on the other a breakdown of the local building and public-works sector. Outside the construction effects, studies can find both the existence and the absence of effects, whether these are short-term effects on local productivity and the geography of consumption (through tourism or extended stays) or long-term effects on the relocation of businesses and households and ultimately growth patterns.

These results in fact show great variability as effects become conditional upon a set of other factors such as city size, amenities, industry structure, and distance from the urban core. The main difficulty that remains is being able to discern to what extent infrastructure may have affected variations observed in the field, and not the opposite. Also, the continuity in the evaluation process should be granted by authorities, in addition of conducting analyses based on sound empirical methods and detailed local data. For that purpose, socioeconomic appraisals must be realized not only ex ante, but also at the various stages of the project's lifetime, which requires constant efforts for data collection and consolidation. Finally, one must keep in mind that the positive economic effects of HSR, if they exist, should always be contrasted with the corresponding costs, be they linked to the initial investment or to some negative spillovers' effects.
We believe that making progress on these questions requires clarifying which model of development is to be used and what kind of development is the goal of public policy. Identifying potential effects only make sense if we can clearly present the preferred type of development and the mechanisms through which these dynamics should be generated. However, difficulties often arise because development is defined implicitly. The problem is then less the dynamics of the effect and more the absence of a clear definition of the development desired for the region, no matter what the scale. This is not to say that HSR makes no difference in existing dynamics but that it operates within the framework of a process driven by the economic actors. Understanding the rationale of these actors should now guide the support strategies that have proven to be essential.

Acknowledgements We would like to acknowledge the two anonymous reviewers for useful comments.

Open Access This article is distributed under the terms of the Creative Commons Attribution 4.0 International License (http:// creativecommons.org/licenses/by/4.0/), which permits unrestricted use, distribution, and reproduction in any medium, provided you give appropriate credit to the original author(s) and the source, provide a link to the Creative Commons license, and indicate if changes were made.

\section{References}

1. Abiad A, Furceri D and Topalova P (2015). The Macroeconomic Effects of Public Investment: Evidence from Advanced Economies. IMF Working Paper, WP/15/95, $26 \mathrm{p}$

2. Ahlfeldt GM and Feddersen A (2015). From Periphery to Core: Measuring Agglomeration Effects Using High-Speed Rail. SERC Discussion Paper, 172, 63 p.

3. Albalate D, Bel G (2012) High-speed rail: lessons for policy makers from experiences abroad. Public Adm Rev 72(3):336-349

4. Albalate D, Bel G, Fageda X (2012) Beyond the efficiency-equity dilemma: centralization as a determinant of government investment in infrastructure. Pap Reg Sci 91(3):599-615

5. Albalate D, Bel G (2012) The economics and politics of highspeed rail. Lexington Books, Lessons from Experiences Abroad, p 210

6. Alegre P, Pou L (2006) The length of stay in the demand for tourism. Tourism Mangement 27(2006):1343-1355

7. Atack, J., Bateman, F., Haines, M. and Margo, R. (2009), Did railroads induce or follow economic growth? Urbanization and population growth in the American Midwest, 1850-60, NBER Working Paper, $\mathrm{n}^{\circ} 14640$

8. Baldwin R, Forslid R, Martin P, Ottaviano G, Robert-Nicoud F (2005) Economic geography and public policy. Princeton University Press, $504 \mathrm{p}$

9. Bazin S, Beckerich C, Delaplace M (2010) Grande vitesse, activation des ressources spécifiques et développement du tourisme urbain: le cas de l'agglomération rémoise. Belgeo 1-2:65-78

10. Bazin S, Beckerich C, Delaplace M (2011) High speed railway, service innovations and urban and business tourisms development, In: Sarmento, M. And Matias, A. Economics and Management of Tourism: Trends and Recent Developments. 
Universidade Luisiada Editora, Lisboa, Portugal, Collecçao Manuais, 422p

11. Bazin S, Beckerich C, Delaplace M (2013) Desserte TGV et villes petites et moyennes, une illustration par le cas du tourisme à Arras. Auray, Charleville-Mézières et Saverne, Les Cahiers Scientifiques du Transport, n 63:33-62

12. Bazin S, Beckerich C, Blanquart C and Delaplace M (2013). Les enjeux et opportunités des dessertes ferroviaires à grande vitesse en matière de développement local et de développement durable, rapport final, contrat PREDIT, financement ADEME, mai, $186 \mathrm{p}$

13. Bernard AB, Moxnes A and Saito YU (2015). Production Networks, Geography and Firm Performance. NBER Working Paper, 21082

14. Blanquart C (1998). Infrastructures de transport et développement: l'apport de l'économie des réseaux. Thèse de doctorat en sciences économiques, juillet, $248 \mathrm{p}$

15. Blanquart, C. (2009). Transport, développement économique et développement durable. Tome 1 du mémoire d'habilitation à diriger les recherches, décembre, 125p

16. Blum U, Haynes KE, Karlsson C (1997) Introduction to the special issue: the regional and urban effects of high speed trains. Ann Reg Sci 31(1):1-20

17. Bonnafous A (1987) The regional impact of the TGV. Transportation 14:127-137

18. Bonnafous, A. (2014). Permanent Observatories as Tools for ExPost Assessment: The French Case Study. ITF-OECD Discussion Paper, n 10, $32 \mathrm{p}$

19. Bouba-Olga O, Grossetti M (2015) La métropolisation, horizon indépassable de la croissance économique ? Revue de l'OFCE 143:117-144

20. Brocker J, Meyer N, Schneekloyh N, Schurmann C, Spierkermann K and Wegener M (2004). Modelling the socioeconomic and spatial impacts of EU transport policy, IASON Deliverable 6 , funded by $5^{\text {th }}$ Framework RTD Programme, Kiel-Dortmund

21. Broyer S, Gareis J (2013) How large is the infrastructure multiplier in the euro area? Natixis Flash Economics 227:8 p

22. Burmeister A, Colletis-Wahl K (1997) Proximity in production networks; the circulatory dimension. European Urban and Regional Studies 4(3):231-241

23. Button K (2012) Is there any economic justification for high-speed railways in the United States? J Transp Geogr 22:300-302

24. California High-Speed Rail Authority and Federal Railroad Administration (2012). Merced to Fresno Section California High-Speed Train (HST) Final Project Environmental Impact Report/Environmental Impact Statement (EIR/EIS) and Final Section 4(f) Statement and Draft General Conformity Determination. Volume I: Report. Sacramento, CA, and Washington, DC.

25. Campos, J. and Gagnepain, P. (2009). Measuring the Intermodal Effects of High-Speed Rail. In: de Rus (ed.), Economic Analysis of High-Speed Rail in Europe, Report prepared for the Foundation BBVA, $140 \mathrm{p}$

26. Castells A, Sole-Olle A (2005) The regional allocation of infrastructure investment: the role of equity, efficiency and political factors. Eur Econ Rev 49(5):1165-1205

27. Cervero R and Bernick M (1996). High-Speed Rail and Development of California's Central Valley: comparative Lessons and Public Policy Considerations. IURD Working Paper 675

28. Charnoz P, Lelarge C and Trevien C (2016). Communication Costs and the Internal Organization of Multi-Plant Businesses: Evidence from the Impact of the French High-Speed Rail, Document de Travail de la Direction des Etudes et Synthèses Economiques - INSEE, G2016/02, 51 p
29. Chen X (2013) Assessing the impacts of high speed rail development in China's Yangtze River Delta megaregion. Journal of Transportation Technologies 3:113-122

30. Chen G and de Abreu e Silva J (2011). The regional impacts of high speed rail; a review of methods and models. Proceedings of the European Transport Conference. 19p

31. Chen Z and Haynes K (2012). Tourism Industry and High Speed Rail, Is There a Linkage: Evidence from China's High Speed Rail Development. In: colloque Industrie, villes et régions dans une économie mondialisée, ASRDLF. Belfort. 9 au 11 juillet

32. Cheng Y-H (2009) High-speed rail in Taiwan: new experience and issues for future development. Transp Policy 17(2):51-63

33. Cheng Y-S, Loo BPY, Vickerman R (2015) High-speed rail networks, economic integration and regional specialization in China and Europe. Travel Behaviour and Society 2:1-14

34. Cohen, I., Freiling T. and Robinson, E. (2012). The economic impact and financing of infrastructure spending, report prepared for associated equipment distributors (AED), $49 \mathrm{p}$.

35. Combes PP, Mayer T, Thisse JF (2006) Economie géographique: l'intégration des régions et des nations. Economica, p 400

36. Combes PP, Duranton G, Gobillon L (2008) Spatial wage disparities: sorting matters! J Urban Econ 63(2):723-742

37. Combes PP and Lafourcade, M (2012). Revue de la literature académique quantifiant les effets d'agglomération sur la productivité et l'emploi, Rapport réalisé pour la Société du Grand Paris, p 64

38. Combes PP, Duranton G and Gobillon L (2012). The costs of agglomeration: Land prices in French cities. CEPR Discussion Paper, No. 9240, p 48

39. Crozet Y (2016). Regional Impacts of High-Speed Rail and CrossChanel Rail System in France: Accessibility is not Enough, Paper presented at the Third International Conference "Twenty years under the Chanel and beyond", Canterbury

40. Crozet Y (2016) Appraisal methodologies and the limits to speed gains. Paper presented at the WCTR, Shangai

41. Davezies L (2008) La république et ses territoires : la circulation invisible des richesses. La République des Idées, Editions du Seuil, p 110

42. DB INTERNATIONAL GMBH (2011). High Speed Rail as a tool for regional development, étude approfondie, 8 août.

43. Delaplace M (2012) Pourquoi les "effets" TGV sont-ils différents selon les territoires? L'hétérogénéité au cœur du triptyque "Innovations, Territoires et Stratégies". Recherche Transports Sécurité 28:290-302

44. Delaplace M, Perrin J (2013) Multiplication des dessertes TGV et Tourismes urbains et d'affaires, Regards croisés sur la Province et l'Ile de France. Recherche Transport et Sécurité 29:177-191

45. Delaplace M, Bazin S, Pagliara F, Sposaro A (2014) High speed rail system and the tourism market: between accessibility, image and coordination tool, $54^{\text {th }}$ European regional science association congress. August, Saint Petersburg, Russia, p 13

46. Department for Transport (2014). Transport Analysis Guidance: Wider Economic Impacts, TAG Unit A2.1, Londres, Accessible en ligne

47. Dobes L, Leung J (2015) Wider economic impacts in transport infrastructure cost-benefit analysis - a bridge too far? Agenda 22(1):75-95

48. Donaldson D (2009). Railroads of the raj: estimating the impact of transportation infrastructure. Mimeo London School of Economics.

49. Duranton G and Puga D (2003). Micro-foundations of urban agglomeration economies. NBER Working Paper, n 9931

50. Eyles L (2013). HS2 - Jobs Analysis, Report prepared by Albion Economics, $19 \mathrm{p}$. 
51. Feliu J (2012) High-speed rail in European medium-sized cities: stakeholders and urban development. Journal of Urban Planning and Development 138:293-302

52. Fernandez-Macho, J., Bhogal, P., Diaz-Emparanza, I. and Gonzalez, P. (2012). Economic impact of the New Basque Railway Network on the BCAC. In: Gasco, E. (ad.), The Basque Y: A country's project, an international connection, Departamento de Vivienda, Obras Públicas y Transportes, $256 \mathrm{p}$

53. Fouqueray E (2016) Impact économique de la construction de la LGV SEA Tours-Bordeaux sur les régions traversées. Revue d'Economie Régionale et Urbaine 2(2016):385-416

54. Fouqueray, E. and Manceau Antoniazzi, E. (2016). Construction de la LGV SEA Tours-Bordeaux et politique de l'emploi: analyse de la coordination des acteurs publics et privés, Géographie, Economie et Société (forthcoming).

55. Gibb RA (1986) The impact of the channel tunnel rail link on south East England. Geogr J 152(3):335-350

56. Givoni M (2006) Development and impact of the modern highspeed train: a review. Transp Rev 26(5):593-611

57. Glaeser EL, Kohlhase JE (2003) Cities, regions and the decline of transport costs, Discussion paper $n^{\circ}$ 2014. Research, Harvard Institute of Economic, $54 \mathrm{p}$

58. Graham DJ (2007) Agglomeration, productivity and transport investment. Journal of Transport Economics and Policy 41(3):317343

59. Graham DJ (2007) Variable returns to agglomeration and the effect of road traffic congestion. J Urban Econ 62(1):103-120

60. Graham DJ, Kim HY (2008) An empirical analytical framework for agglomeration economies. Annals of Regional Sciences 42: 267-289

61. Graham DJ, Melo PC (2011) Assessment of wider economic impacts of high-speed rail for great Britain. Transportation Research Record: Journal of the Transportation Research Board 2261:1524

62. Graham DJ, Brage-Ardao R, Melo P (2013) Measuring the impact of high-speed rail on economic performance: evidence for the Madrid-Barcelona corridor. In: Paper presented during the Transportation Research Board (TRB) annual meeting, 92nd. DC, Washington

63. Hall P (2009) Magic carpets and seamless webs: opportunities and constraints for high-speed Trains in Europe. Built Environ 35(1): 59-69

64. Hensher DA, Ellison RB, Mulley C (2013) Assessing the employment agglomeration and social accessibility impacts of high-speed rail in eastern Australia. Transportation 41:463-493

65. Hoyt H (1954) Homer Hoyt on development of Economic Base concept. Land Econ 30(2):395-403

66. Hornung E (2012). Railroads and micro-regional growth in Prussia. Competitive Advantage in the Global Economy (CAGE) No. 79

67. Kamel, K. and Matthewman, R. (2008), The non-transport impacts of High-Speed Trains on regional economic development: a review of the literature, Locate in Kent, online report, http://www.locateinkent.com/images/assets/High\%20Speed\%20 Train\%20Report\%202008.pdf

68. Kanemoto Y (2013). Pitfalls in Estimating Wider Economic Benefits of Transportation Projects, GRIPS Discussion Paper, $13-20,31 \mathrm{p}$

69. Klein O and Claisse G (1997). Le TGV Atlantique: entre recession et concurrence. Lyon, LET

70. Koning, M., Bahoken, F., Bazin Benoit, S., Beckerich, C., Blanquart, C., Delaplace, M., Joignaux, G. and Savy, M. (2015). BASECOGV - Dessertes TGV et dynamiques économiques locales: un éclairage à partir de la distinction entre territoires productifs, résidentiels ou intermédiaires, Rapport de recherche pour le PREDIT, 19e7 p
71. KPMG (2013). HS2 Limited - HS2 Regional Impacts, report prepared for Department for Transport, $95 \mathrm{p}$

72. Krikelas AC (1992) Why regions grow: a review of research on the Economic-Base model. Economic Review Federal Reserve Bank of Atlanta:16-29

73. Lafourcade M and Thisse JF (2011). New Economic Geography: The Role of Transport Costs. In: Handbook of Transport Economics, A.de Palma, R. Lindsey, E. Quinet and R. Vickerman (eds.), Edward Elgar Publishing Ltd, Cheltenham.

74. Leboeuf, M. (2013), Grande Vitesse ferroviaire, Cherche Midi, 853e p.

75. Levinson DM (2012) Accessibility impacts of high-speed rail. J Transp Geogr 22:288-291

76. Lynch T (2000). Analyzing the economic impact of transportation project using RIMS II, IMPLAN and REMI, Report prepared for the US Department of Transportation - Office of Research and Special Programs, $40 \mathrm{p}$

77. Mannone V (1995) L'impact régional du TGV sud-est. In: Thèse pour l'obtention du doctorat de géographie. Université de Provence, Aix-Marseille I

78. Martin P (1999) Public policies, regional inequalities and growth. J Public Econ 73(1):85-105

79. Martin N, Bourdeau P, Daller JF (2012) Les migrations d'agrément: du tourisme à l'habiter. Paris: L'Harmattan p 408

80. Martinez Sanchez-Mateo HS, Givoni M (2009) The accessibility impact of a new high-speed rail line in the UK - a preliminary analysis of winners and losers. TSU Working Paper 1041:18

81. Masson S, Petiot R (2009) Can the high speed rail reinforce tourism attractiveness? The case of the high speed rail between Perpignan (France) and Barcelona (Spain). Technovation 29(9): 611-617

82. McCann P (2001) Urban and Regional Economics. Oxford University Press, Oxford, p 304

83. Mayer T and Head K (2003). The empirics of agglomeration and trade. CEPII Working Paper, n 15.

84. Melo PC, Graham DJ, Noland RB (2009) A meta-analysis of estimates of urban agglomeration economies. Reg Sci Urban Econ 39(3):332-342

85. Nakagawa D, Hatoko M (2007) Reevaluation of Japanese highspeed rail construction: recent situation of the north corridor Shinkansen and its way to completion. Transp Policy 14(2):150 164

86. OCDE (2002). Investissements en infrastructure de transport et développement régional. Editions de l'OCDE, Paris, p 167

87. Offner JM (1993) Les «effets structurants» du transport: mythe politique, mystification scientifique. L'espace géographique 22(3):233-242

88. Ollivier G, Ying J, Bullock R, Runze Y and Nanyan Z (2014). Regional Economic Impact Analysis of High-Speed Rail in China, Report for the World Bank and the People's Republic of China, ACS9734, $120 \mathrm{p}$

89. Preston J, Larbie A, Wall G (2006) The Impact of High Speed Trains on Socio-Economic Activity: The case of Ashford (Kent), 4th annual conference on railroad industry structure, competition and investment. Universidad Carlos III, Madrid

90. Preston J, Wall G (2008) The ex-ante and ex-post economic and social impacts of the introduction of high speed trains in south East England. Plan Pract Res 23(3):403-422

91. Prideaux B (2000) The role of the transport system in destination development. Tourism Management, n 21:53-63

92. Proost $\mathrm{S}$ and Thisse J-F (2015). Skilled cities, Regional Disparities and Efficient Transport: The State of the Art and a Research Agenda, CEPR Discussion Paper, $100 \mathrm{p}$

93. Puga D (2002) European regional policy in light of recent location theories. J Econ Geogr 2(4):373-406 
94. Réseau Ferré de France (2010). Les retombées économiques et sociales du chantier, Les cahiers de la LGV Rhin-Rhône 1:60

95. Richardson H-W (1985) Input-output and economic base multipliers: looking backward and forward. J Reg Sci 25(4):607-661

96. Rietveld, P., Bruinsma, F., Van Delft, H. and Ubbels, B. (2001). Economic Impacts of High Speed Trains. Experiences in Japan and France: Expectations in The Netherlands, Serie Research Memoranda (de Faculteit der Economische Wetenschappen en Bedrijfskunde), $\mathrm{n}^{\circ} 20$.

97. de Rus G (ed.), Barron I, Campos J, Gagnepain P, Nash C, Ulied A and Vickerman R (2009). Economic Analysis of High-Speed Rail in Europe, Report prepared for the Foundation BBVA, $140 \mathrm{p}$

98. Sands BD (1993). The Development Effects of High-Speed Rail Stations and Implications for California, Institute of Urban and Regional Development, University of Berkeley, <http://www. uctc.net/papers/115.pdfs

99. SEEDA - SOUTH EAST ENGLAND DEVELOPMENT AGENCY (2008). HST Impact Study, rapport final pour la Commission européenne, <http://www.ttr-1td. com/downloads/pdf/HSTImpactStudyFinalReportES.doc.pdf

100. SETEC INTERNATIONAL (2011). Calcul des performances économiques et naturelles liées à l'accessibilité, Rapport $\mathrm{n}^{\circ} 2$ pour RFF, $81 \mathrm{p}$

101. Shields M, Deller SC (1998) Commuting effects on local retail market performance. Review of regional studies 1998(28-2):7189

102. Standing Advisory Committee on Trunk Road Assessment (1999) Transport and the economy: full report. Department for Transport, London

103. Short J, Kopp A (2005) Transport investment: investment and planning. Policy and research aspects. Transp Policy 12:360-367

104. Sombart W (1902) Der Moderne Kapitalismus. Duncker and Humblot, p 711

105. Spiekermann K, Wegener M (1994) The shrinking continent: new time-space maps of Europe. Environment and Planning B: Planning and Design 21(6):653-673

106. Tiebout CM (1956) The urban economic base reconsidered. Land Econ 32(1):95-99

107. Todorovich, P., Schned, D. and Lane R. (2011). High-Speed Rail: International Lessons for U.S. Policy Makers, collection Policy Focus Report, Cambridge: Lincoln Institute of Land Policy. $64 \mathrm{p}$
108. Troin J-F (2012). TGV et fréquentation touristique: une image contrastée en Val de Loire. Communication présentée dans le cadre du colloque Industrie, villes et régions dans une économie mondialisée, ASRDLF. Belfort. 9 au 11 juillet.

109. Urena, J. (ed), (2016). Territorial Implications of High Speed Rail: A Spanish Perspective, Routledge, 308p.

110. Urena, J., Menendez, J. M and Guirao, B. (2005). Alta velocidad ferroviaria e integración metropolitana en España: el caso de Ciudad y Puertollano, Eure-Revista latinoamericana de Estudios Urbano Regionales, $\mathrm{n}^{\circ}$ 92, p. 87-104

111. Urena J, Menerault P, Garmendia M (2009) The high-speed rail challenge for big intermediate cities: a national, regional and local perspective. Cities 26(5):266-279

112. Venables T (2007) Evaluating urban transport improvements: cost-benefit analysis in the presence of agglomeration and income taxation. Journal of Transport Economics and Policy 41(2):173188

113. Venables, A. (2015). Incorporating wider economic impacts within cost-benefit appraisal, ITF-OECD Discussion Paper, 29 p

114. Vickerman R (2007) Cost-benefit analysis and large-scale infrastructure projects: state of the art and challenges. Environment and Planning B 34(4):598-610

115. Vickerman R and Ulied A (2009). Indirect and Wider Economic Impacts of High-Speed Rail, In: de Rus (ed.), Economic Analysis of High-Speed Rail in Europe, Report prepared for the Foundation BBVA, p 140

116. Wang, X., Huang, S., Zou, T. and Yan, H. (2012). Effects of the high speed rail network on China's regional tourism development, Tourism Management Perspectives, $\mathrm{n}^{\circ} 1$, p. 34-38

117. Weinstein, O (1989). Modes de coordination intra et interentreprises et modeles d'innovation, in C. Palloix and Y. Rizopoulos (eds.), Firmes et économie industrielle, L'Harmattan

118. Weinstein O (1997). Sur les modes de coordination et les relations interentreprises, Séminaire de l'ADIS, février

119. Woodside AG, Lysonski S (1989) A general model of traveler destination choice. J Travel Res 27(4):8-14

120. Wu J (2013) Financial and economic assessment of China's highspeed rail investments. ITF-OECD Discussion Paper 28:40

121. Wubneh M (2008). US Highway 17 and its impact on the economy of eastern North Carolina, Report prepared for Highway 17 Association, p 48 